\title{
THE SCHOOL OF EDUCATION AT RUTGERS: FIFTY YEARS
}

\author{
BY RICHARD G. DURNIN
}

Dr. Durnin, who teaches historical and social foundations of education at

The City College, City University of New York, is a former member of the faculty at the Graduate School of Education at Rutgers.

\section{Beginnings}

The Graduate School of Education at Rutgers University marks its fiftieth anniversary this year. It was in October of 1923 that the Trustees created the School of Education out of what was then a college department.

From the beginning of the early American colleges, many a young graduate went out as a schoolmaster; some only for a short time (perhaps while they read law or theology), some in addition to other callings (often as a clergyman), and fewer as a full-time vocation (and these not as common schoolteachers, but as Latin grammar masters, academy masters, and later as high school teachers). There was no conscious preparation for the profession of teaching aside from on-the-job experience. At college all scholars pursued the same classical curriculum until the nineteenth century was well along.

Since John Bogart, of the class of I 778 at Queens College (as Rutgers was known before 1825 ), went out as a schoolmaster, the institution, from Dutch Reformed Church days through its transformation into the State University, has prepared thousands of teachers and school administrators. Young Bogart (who intended to study for the ministry) began to teach at the Grammar School attached to Queens College forthwith upon his graduation. The alumni rolls of the College in the mid-nineteenth century show former students teaching at, or as headmasters of, academies. Among the prominent educators of this period was Ellis A. Apgar (class of 1866) who was New Jersey State Superintendent of Public Schools from I 866 to I 885 .

The slow development of free, public high schools in New Jersey up to 1875 was the principal reason for the inaction on the part of 
the state or at Rutgers in the preparation of teachers for this level of education. The New Jersey Constitution of 1875 made provisions for free schooling of children between the ages of five and eighteen. Then the impetus for public secondary schools was present, and after I 890 their growth was rapid. New teachers for these schools were required to hold the baccalaureate degree beginning in I9I I. All of these factors tended to bring about a response from Rutgers in the matter of teacher training.

An elective course at the College for those who intended to teach was proposed as early as I 853 , but nothing came of it and over thirty years passed before such an offering was available. However, Rutgers did have on its faculty an early "educationist" of note. He was David Murray who came in I 863 as professor of mathematics. Murray became an educational adviser to the government of Japan a decade later and served there until I 879. While in New Brunswick he often gave papers before the local historical society, the first being "The Early History of Queens College." He was the author of the first history of education in New Jersey (History of Education in New Jersey, Washington, I 899).

The first appearance of a course for teachers at Rutgers was for the term beginning September of I 886 when lectures (one hour per week) were prescribed for the senior class on "The Science and Art of Teaching," along with some lectures on history and social science. There is no indication in the catalogue as to who gave the lectures, but it is conceivable that it was Austin Scott, the professor of history and an extraordinary teacher (later to become president of Rutgers). It is somewhat surprising that the lecture on teaching was required of all seniors in the classical curriculum. But where the ministry was a calling for many youth earlier, by this point in the century teaching may have appealed to as many (and then public secondary schools were appearing).

\section{Department of Education}

Eliot R. Payson, who came as Headmaster of the Rutgers Preparatory School in I 89I, was named, in addition, as "Professor of the History and Art of Teaching." This was Rutgers' first professorship in education, albeit a part-time one. His course, appearing first in the program for September I 893, "Pedagogy-Lectures," was required 
of all classical students in the third term of the senior year (and optional to any others who intended to teach). The major educational classics were read. The course became an elective beginning in 1907. Professor Payson left the headmastership at the Preparatory School in 1908 and became full-time teacher at the College (he taught German as well as education). His was a long tenure-it lasted until June 1930. It was reported by the Targum in 1928 that he was voted the most popular and humorous teacher on campus. The Graduate School of Education today has a titled chair, the "Eliot R. Payson Professor," in his honor.

Myron T. Scudder (class of I 882) replaced Payson at the Preparatory School in September of i 908. He was also appointed "Professor of the Science of Teaching," and gave two courses on the principles and practice of teaching. He left the College in I9I I.

The first full-time appointment in education was that of Alexander J. Inglis who came in I 912 as "Professor of the Science of Teaching." Professor Inglis went on to Harvard in 1915 , and subsequently became a recognized authority on secondary education. The "science" in the professorial title was significant: educational psychology (using Thorndike) now appeared in the curriculum. By I9I3 there were seven courses offered including such new ones as educational sociology and administration.

Charles H. Elliott was named in I9 5 to replace the departing Inglis, and held the title "Professor of the Science of Education." $\mathrm{He}$ also served as Director of the Summer Session (Professor Inglis had previously done so). The Summer Session attracted teachers-inservice from the outset, in I9I3, when it came under the direction of the Department of Agriculture. Soon after, it came under the Department of Education where it remained for many years. Degrees were not earned at this time through summer study, only credits toward teaching certificates, with women students predominating. As was the situation in many universities at this time, the first women students came either in summer or in extension as non-matriculants, and they generally pursued courses in education. Douglass College (known first as New Jersey College for Women) came into being in 1918 .

Professor Elliott was asked by President W.H.S. Demarest in I 92 I to work on a plan for the reorganization of Rutgers. The result- 
ing conception suggested a university with several colleges, schools, and divisions, among them a School of Education. The plan was not accepted by the Trustees, but many elements appeared in a subsequent proposal.

\section{School of Education}

Another plan of reorganization was put forth by a committee of ten in 1922, and it was from this one, accepted by the Trustees in that year, that the School of Education came forth, being established on October I2, I923, with Professor Elliott as its first Dean. With the growth of the University, the title "Rutgers University" was authorized and first used in June of 1924.

The aims of the new school were: (I) to prepare students for teaching and supervisory positions in the schools of New Jersey; (2) to offer a program of professional training for teachers now engaged in service; and (3) to cooperate with the schools of New Jersey in the study of problems of teaching and administration. Although sights have long since been lifted to embrace the nation's schools and international education, the School's departments, degree programs, and institutes have developed out of these objectives.

The I920's and I930's were growth years for the School of Education. The degree of Bachelor of Science in Education was approved by the Trustees in 1925. This degree was intended essentially for in-service elementary school teachers, many of whom had earlier attended state normal schools for fewer than four years (New Jersey's state normal schools awarded degrees beginning in 1925). By I 929 the Rutgers School of Education was the largest division of the University, and in the decade I 930 to I 940 the enrollment of the school doubled. The extension program enrolled 5,375 teachers at 42 centers throughout New Jersey. This institutional growth took place under Dean Clarence E. Partch who came to the post in I928.

The graduate degrees of Master of Education and Doctor of Education were authorized in 1930 . The first doctorate in education was awarded to Abraham Lucius Lincoln in June of I93 I for the dissertation "Individualized Instruction in First Year Latin." The graduates in education grew in such numbers that a separate commencement was held for many years.

Professional fraternities and honor societies were established at the 
School beginning with Alpha Pi Chapter of Phi Delta Kappa (a men's professional fraternity) in I932. Following in I 935 came $\mathrm{Nu}$ Chapter of Epsilon Pi Tau (vocational education), and in 1938 Delta Xi Chapter of Kappa Delta Pi (the coeducational undergraduate and graduate honor society).

No chronicle of the I930's at Rutgers would be complete without mention of Professor Oscar K. Buros and his work in educational testing. He came as an Assistant Professor in 1932 and retired in I 965 (but is still very busy with his research on tests). During these 33 years he taught many courses, held administrative assignments, wrote widely in his field, prepared the Mental Measurements Yearbook (the first in 1938), and in 1946 became Director of the Institute of Mental Measurements.

The depression years found the School of Education more than holding its own financially within the University. Indeed, it was a major income-producing unit.

On the eve of World War II, in I94I, Rutgers observed its I 75th anniversary, and soon after there was a great change in campus population. The war drained off many faculty and students. The School of Education was, of course, affected too. From these most difficult years, the University emerged as a transformed institution: in March of I945 Rutgers was designated "The State University of New Jersey." Newark College came under its jurisdiction when it merged with Rutgers in July of 1946, and the College of South Jersey in Camden came into the union in 1950. Both of these locations were to have branches of the School of Education.

Dean Partch went on terminal leave in $195 \mathrm{I}$, and his post was filled by Professor J. Donald Neill as Acting Dean. Henry Curtis Herge arrived as the third Dean of the School in the summer of 1953. Under Dean Herge's eleven-year administration the School of Education moved ahead rapidly to adjust to the needs of a growing and changing school system and encompassed new areas of concern.

\section{Graduate School of Education}

Departmentalization, the Division of Field Services, the Instructional Materials Center, programs for visiting foreign teachers, attention to the problems of urban education, the transformation into 
a graduate school, and the move into a new building are among the accomplishments under Dean Herge's administration.

Increasingly, during the I950's, the emphasis at the School had moved towards graduate work both at the master's and doctorate level. Undergraduates in physical education and secondary school teacher training matriculated under the College of Arts and Sciences with their taking only a few required courses in education. The parttime baccalaureate work for in-service teachers had come to an end. So the School of Education became the Graduate School of Education in name as well as in practice in April of 1960.

The new building for the School was one of the tangible results of the 1959 New Jersey bond issue for higher education. Located on the site of tennis courts on Seminary Place, ground was broken for the structure in June of $196 \mathrm{I}$, and it was opened for use in January of I963. It consolidated in a four-level building the strung-out and cramped facilities located in five old buildings.

Dean Herge resigned his post and went on a year's leave of absence at the end of the 1964 spring term. Upon his return he has served as Professor of Education in the Department of Social and Philosophical Foundations of Education and as Program Associate for the University Center for International Programs.

John J. O'Neill served as the School's fifth Dean from I 964 to I 967 . It was during his years, in I 966 , that the University celebrated the 2ooth anniversary of its founding. Dean O'Neill resigned the office in the spring of 1967 and was replaced by Milton Schwebel, the current Dean, in the fall of that year.

Programs are currently offered at the graduate level in many specialties under these areas of study: Educational Administration and Supervision, Psychological Foundations, Science and Humanities Education, Social and Philosophical Foundations, and VocationalTechnical Education.

Dean Schwebel, in looking beyond the fifty years, has written that Rutgers Graduate School of Education is

dedicated to the improvement of education through the study of its problems in a joint venture of our students and faculty working collaboratively with those in schools. ... The process brings pleasure and pain, satisfaction and frustration. These ... are inevitable . . f for those who confront the big problems of our time. 


\section{References:}

Announcements and Catalogues of the School of Education and Graduate School of Education at Rutgers.

Catalogues of Officers and Students of Rutgers College.

Catalogue of the Officers and Alumni of Rutgers College, from 1770 to $187 \mathrm{I}$ (New Brunswick, I872).

Demarest, William H. S., A History of Rutgers College, 1766-1924 (New Brunswick: Rutgers College, I924).

McCormick, Richard P., Rutgers: A Bicentennial History (New Brunswick: Rutgers University Press, 1966).

Various pamphlets, reports, and records pertaining to the School of Education in the University Archives, Rutgers University Library. 